\title{
Effectiveness of Sodium Polystyrene Sulfonate for Short-Term Treatment of Hyperkalemia
}

\author{
Josh Batterink, Jane Lin, Sarah Hin Mui Au-Yeung, and Tara Cessford
}

\begin{abstract}
Background: Sodium polystyrene sulfonate (SPS) is a potassium-binding resin that is commonly used to treat mild hyperkalemia. However, there is limited evidence supporting its effectiveness in the short-term management of hyperkalemia.
\end{abstract}

Objective: To determine whether SPS is effective in reducing serum potassium in general medical patients after a single oral dose.

Methods: A retrospective observational study was conducted for patients admitted to the internal medicine service of a tertiary care hospital between January 2011 and May 2012 with documentation of a serum potassium level between 5.0 and $5.9 \mathrm{mmol} / \mathrm{L}$ during the hospital stay. Patients eligible for inclusion were adults without chronic or acute renal failure or recent changes in medication or diet that would affect serum potassium level. Propensity score matching was performed to minimize differences between the control group (no treatment) and the treatment group (treatment with oral SPS). Follow-up serum potassium levels (at 6-24 h) were compared with index potassium levels.

Results: A total of 138 patients met the inclusion criteria, 72 in the control group and 66 in the treatment group. For most patients in the treatment group, the dose was 15 or $30 \mathrm{~g}$ of SPS orally. The difference between the control and treatment groups in terms of mean change in serum potassium at 6 to $24 \mathrm{~h}$ after the index potassium measurement was statistically significant (by paired $t$ test) in both an unmatched analysis $(-0.41 \pm 0.50$ and $-0.58 \pm 0.39 \mathrm{mmol} / \mathrm{L}$, respectively; $p=0.039)$ and a matched analysis $(-0.44 \pm 0.29$ and $-0.58 \pm 0.39 \mathrm{mmol} / \mathrm{L}$, respectively; $p=0.026)$. No difference was observed in terms of mean change in serum potassium between patients who received 15 and $30 \mathrm{~g}$ of SPS $(-0.51 \pm$ 0.38 and $-0.66 \pm 0.40 \mathrm{mmol} / \mathrm{L}$, respectively; $p=0.13$ ).

Conclusions: In patients with mild hyperkalemia, oral SPS therapy reduced serum potassium by $0.14 \mathrm{mmol} / \mathrm{L}$ more than control. Although this difference was statistically significant, the small treatment effect observed in this study may not be clinically important. Furthermore, the cost and potential adverse effects of treatment suggest that routine use of SPS may be inappropriate for patients with mild hyperkalemia. Prospective randomized controlled trials would help in further evaluating the effectiveness and safety of SPS.

Keywords: sodium polystyrene sulfonate (SPS), hyperkalemia, Kayexalate

\section{RÉSUMÉ}

Contexte : Le sulfonate de polystyrène sodique (SPS), une résine qui fixe le potassium, est fréquemment employé pour traiter l'hyperkaliémie légère. Or, peu de données appuient son efficacité réelle dans le traitement à court terme de ce trouble.

Objectif : Déterminer si le SPS permet de réduire les taux sériques de potassium chez les patients traités en médecine générale après administration d'une seule dose par voie orale.

Méthodes : Une étude d'observation rétrospective a porté sur des patients hospitalisés au service de médecine interne d'un centre hospitalier de soins tertiaires entre janvier 2011 et mai 2012 qui ont présenté des taux sériques de potassium entre 5,0 et 5,9 mmol/L durant leur séjour. Seuls étaient admissibles à l'étude les patients adultes sans insuffisance rénale chronique ou aiguë et sans changement récent à leur pharmacothérapie ou à leur diète qui pourrait influencer leur taux de potassium sérique. Un appariement par scores de propension a été réalisé afin de réduire au minimum les différences entre le groupe témoin (sans traitement) et le groupe traité (administration de SPS par voie orale). Les kaliémies de contrôle (de 6 heures à 24 heures plus tard) ont été comparées aux indices d'hyperkaliémie.

Résultats : En tout, 138 patients ont satisfait aux critères d'inclusion; 72 ont été placés dans le groupe témoin et 66 dans le groupe traité. La dose de SPS administrée aux patients du groupe traité était généralement de $15 \mathrm{~g}$ ou de $30 \mathrm{~g}$ par voie orale. En ce qui concerne le changement moyen des taux sériques de potassium mesurés de 6 à 24 heures suivant les indices d'hyperkaliémie, la différence entre le groupe témoin et le groupe traité était statistiquement significative (selon un test $t$ pour échantillons appariés), et ce, autant dans une analyse non appariée (respectivement $-0,41 \pm 0,50$ et $-0,58 \pm 0,39 \mathrm{mmol} / \mathrm{L} ; p=0,039)$ que dans une analyse appariée (respectivement $-0,44 \pm 0,29$ et $-0,58 \pm 0,39 \mathrm{mmol} / \mathrm{L}$; $p=0,026)$. Aucune différence n'a été observée en ce qui a trait au changement moyen des taux sériques de potassium entre les patients ayant reçu $15 \mathrm{~g}$ de SPS et ceux en ayant reçu $30 \mathrm{~g}$ (respectivement $-0,51 \pm 0,38$ et $-0,66 \pm 0,40 \mathrm{mmol} / \mathrm{L} ; p=0,13)$.

Conclusions : Chez les patients présentant une hyperkaliémie légère traités à l'aide de SPS par voie orale, on a observé une baisse des taux sériques de potassium de $0,14 \mathrm{mmol} / \mathrm{L}$ de plus que chez ceux du groupe témoin. Bien que cette différence fût statistiquement significative, le faible effet thérapeutique relevé dans cette étude pourrait ne pas être 
Can J Hosp Pharm. 2015;68(4):296-303 cliniquement important. De plus, les coûts ainsi que les effets indésirables potentiels du traitement laissent croire que le recours systématique au SPS pourrait être inapproprié pour les patients atteints d'hyperkaliémie légère. Des essais cliniques comparatifs aléatoires prospectifs aideraient à évaluer plus en profondeur l'efficacité réelle et l'innocuité du SPS.

Mots clés : sulfonate de polystyrène sodique, hyperkaliémie, Kayexalate

\section{INTRODUCTION}

Jyperkalemia is common, particularly among hospital in1 patients, and is associated with significant mortality and morbidity. ${ }^{1-6}$ Sodium polystyrene sulfonate (SPS) is a potassiumbinding resin commonly used to treat mild acute or chronic hyperkalemia by increasing the excretion of potassium in stool. ${ }^{7}$ SPS is predominantly used for mild hyperkalemia (defined as serum potassium between 5 and $6 \mathrm{mmol} / \mathrm{L}$ ), where the risk of complications is low. ${ }^{8}$ SPS was approved in 1958 by the US Food and Drug Administration (FDA), before drug manufacturers were required to prove that their products were efficacious. ${ }^{7,9}$ SPS was approved in Canada 3 years later, in $1961 .{ }^{10}$ When SPS was first approved, there were only 2 small nonrandomized studies (both with poor methodology) showing that SPS reduced serum potassium. ${ }^{11,12}$

The effectiveness of SPS was first discussed in 2 studies published in 1961. ${ }^{11,12}$ A preliminary study included 10 oliguric patients with serum potassium between 6 and $7.3 \mathrm{mmol} / \mathrm{L} .{ }^{11}$ The patients were divided into 3 groups, with 5 days of treatment planned for each group. Group 1 patients were given 10-20 mL of $70 \%$ sorbitol syrup orally every $2 \mathrm{~h}$ until a loose bowel movement was produced each day. Group 2 patients were given SPS 5-15 g orally 4 times daily, in addition to oral sorbitol therapy as for group 1 . Group 3 patients received a $200-\mathrm{mL}$ enema daily, which contained $25 \%$ sorbitol and $40 \mathrm{~g}$ of SPS. All patients received $500-700 \mathrm{~mL}$ of fluid daily, either intravenously with dextrose $50 \%$ infusion or orally with a mixture of Karo syrup and ginger ale. On day 5 , the mean serum potassium for patients in groups 1 and 2 was 4.6 and $5.2 \mathrm{mmol} / \mathrm{L}$, respectively. Group 3 was stopped early (at day 2) because one patient experienced hypokalemia. The authors concluded that SPS with sorbitol was effective for treating hyperkalemia in oliguric patients. ${ }^{11}$

The other study involved 32 patients with acute or chronic kidney disease and serum potassium between 4.2 and $9.2 \mathrm{mmol} / \mathrm{L} .{ }^{12}$ All patients received SPS at a dose of either 20-60 g orally or 10-40 g rectally. Patients with acute kidney injury were given infusions of dextrose $20 \%$, and all patients received low-potassium diets. The researchers observed a mean reduction in serum potassium of $1.0 \mathrm{mmol} / \mathrm{L}$ over $24 \mathrm{~h}$, and this study became the main supporting evidence for the use of SPS in hyperkalemia, despite its small sample size, concomitant interventions, and open-label design. ${ }^{12}$

Since 1961, there have been 2 prospective randomized studies evaluating SPS, ${ }^{13,14}$ which showed no benefit, and one retrospective observational study ${ }^{15}$ that did show a benefit. In the first randomized crossover trial of SPS, published in $1995,{ }^{14} 9$ healthy participants were treated with $60 \mathrm{~g}$ of sorbitol with or without $100 \mathrm{mmol}$ SPS. Each participant was then given $40 \mathrm{mEq}$ potassium IV and $23 \mathrm{mEq}$ potassium via food. The primary outcome was the excretion of water, solids, sodium, and potassium in the stool within $12 \mathrm{~h}$. The authors found that SPS contributed little to total fecal excretion of potassium. A randomized crossover trial published in 1998 involved 6 patients undergoing hemodialysis who were treated with $30 \mathrm{~g}$ of SPS with or without $60 \mathrm{~g}$ of sorbitol. ${ }^{13}$ There was no reduction in serum potassium relative to placebo. Finally, a retrospective cohort study published in 2011 evaluated 122 patients with initial serum potassium $5.4-5.9 \mathrm{mmol} / \mathrm{L}$ who were treated with SPS $15 \mathrm{~g}, 30 \mathrm{~g}, 45 \mathrm{~g}$, or 60 g. ${ }^{15}$ Overall, $94 \%$ of the patients had a reduction in serum potassium to less than $5 \mathrm{mmol} / \mathrm{L}$, and the authors found a doseresponse relationship between SPS and the reduction in serum potassium. However, the study had no control group and may not have been adequately controlled for potential confounders.

There have also been several reports of SPS causing adverse outcomes such as colonic necrosis, mucosal lesions, and aspiration pneumonitis. ${ }^{6-8}$ A systematic review evaluated adverse reactions reported between 1948 and July 2011 using the World Health Organization causality assessment criteria and concluded that gastrointestinal adverse effects may be linked to SPS both with and without sorbitol. ${ }^{16}$

Given the lack of strong clinical evidence of effectiveness and the potential for adverse effects, the current study was performed to evaluate the effectiveness of SPS in reducing serum potassium. The hypothesis was that short-term administration of SPS would not reduce the serum potassium level.

\section{METHODS}

This study was a retrospective, single-site review of electronic health care records, conducted at St Paul's Hospital in Vancouver, British Columbia, a tertiary care teaching hospital with over 500 
acute care beds. The hospital's laboratory services department generated a list of all patients admitted to the medicine service between January 2011 and May 2012 who had a documented value for serum potassium between 5.0 and $5.9 \mathrm{mmol} / \mathrm{L}$ during the hospital stay. The patients were screened for eligibility according to predefined inclusion and exclusion criteria. Patients aged 19 years or older, with serum potassium between 5.0 and $5.9 \mathrm{mmol} / \mathrm{L}$, were included. Exclusion criteria were hyperkalemia at the time of admission (unless the patient had been admitted for at least $48 \mathrm{~h}$ with intervening normalization of serum potassium), lack of follow-up serum potassium measurement within $24 \mathrm{~h}$ after the index measurement, acute renal failure, chronic renal failure (creatinine clearance $\leq 15 \mathrm{~mL} / \mathrm{min}$ or receiving hemodialysis or peritoneal dialysis), medication history with unclear or missing information, medication administration record with unclear or missing information about SPS treatment, and potassium-altering dietary or medication change during the index hyperkalemia episode. Identification of acute renal failure was based on the RIFLE criteria (risk, injury, failure, loss, endstage renal disease), whereby renal failure is deemed to be present if serum creatinine triples or is greater than $354 \mu \mathrm{mol} / \mathrm{L}$ with a short-term rise of more than $44 \mu \mathrm{mol} / \mathrm{L}$ or if the glomerular filtration rate declines by more than $75 \% .{ }^{17} \mathrm{~A}$ change in potassium-altering medication was defined as initiation or discontinuation of furosemide, thiazides, bicarbonate, high-dose salbutamol, insulin-dextrose protocol, aminophylline, potassium, potassium-sparing diuretics, angiotensin-converting enzyme (ACE) inhibitors or angiotensin receptor blockers (ARBs), trimethoprim, or $\beta$-blockers. For patients with multiple episodes of hyperkalemia meeting the eligibility criteria, only the first eligible treated episode and the first eligible untreated episode were included. Included patients were assigned to the treatment group if they had received SPS treatment and to the control group if they had not received oral SPS. The formulation of SPS used during the study period contained sorbitol.

The primary outcome was mean change in serum potassium. The time to follow-up measurement of serum potassium ranged from 6 to $24 \mathrm{~h}$ after the index potassium measurement. Secondary outcomes were the relationship between dose of SPS and magnitude of serum potassium reduction and the occurrence of adverse events associated with SPS therapy.

A power analysis was performed to obtain a power of $90 \%$ and $\alpha$ value of 0.05 for demonstrating the equivalence of SPS and placebo for reduction in serum potassium. The minimal clinically important difference in serum potassium reduction was defined as greater than $0.2 \mathrm{mmol} / \mathrm{L} .{ }^{15,18} \mathrm{~A}$ minimum sample size of 50 pairs was required to demonstrate equivalence. Propensity score matching was used to select suitable patients for the control group. The choice of covariates for the final propensity score calculation was based on clinical relevance and frequency of appearance in the study population, with a goal of being inclusive rather than exclusive, as per published recommendations. ${ }^{19}$ Propensity scores were calculated using Stat 12.0 (StataCorp LP, College Station, Texas) and PSmatch2 (http://repec.org/bocode/ $\mathrm{p} / \mathrm{psmatch} 2 . \mathrm{html})$. The same software was used to match treated patients with controls. Matched groups were tested for significant differences using the paired $t$ test. Within the treatment group, the unpaired Student $t$ test was used to compare the $15-\mathrm{g}$ and 30 -g doses to assess for a dose-response relationship. For all $t$ tests, a $p$ value less than 0.05 (2-tailed) was deemed statistically significant. Data were analyzed using Excel 2010 (Microsoft Corp., Redmond, Washington) and Stata 12.0.

This study was approved by the University of British Columbia - Providence Health Care Research Ethics Board and the Fraser Health Research Ethics Board. Written informed consent was not required for this retrospective study.

\section{RESULTS}

A total of 333 patients and 839 potassium measurements were screened. One hundred and thirty-eight of the patients were eligible for study enrolment, 72 in the control group and 66 in the treatment group (Table 1). The most common reasons for exclusion were lack of follow-up serum potassium measurement within $24 \mathrm{~h}$, creatinine clearance less than $15 \mathrm{~mL} / \mathrm{min}$, recent change to a potassium-altering medication, and documented hyperkalemia at the time of hospital admission.

Of the 66 patients who received oral SPS therapy, 1 received a 10 -g dose, 32 received a $15-\mathrm{g}$ dose, 31 received a 30 -g dose, 1 received a $45-\mathrm{g}$ dose, and 1 received a 60 -g dose.

The patients were mostly older men with mild hyperkalemia and normal renal function. About $15 \%$ of the patients had heart failure or liver dysfunction, and about $30 \%$ had diabetes mellitus. Overall, the characteristics of the treatment and control groups were similar before matching (Table 1). The time to follow-up measurement of serum potassium was evenly distributed between 4 and $24 \mathrm{~h}$ in the treatment group, whereas more patients in the control group had follow-up measurement of serum potassium levels after $22 \mathrm{~h}$ (Figure 1).

The results for propensity score matching are shown in Table 2. Before matching, the treatment group had a significantly higher index potassium level and urea level; these differences were eliminated through propensity score matching. The betweengroup differences in use of thiazides or loop diuretics and dalteparin were increased by propensity score matching, but the differences were small and not statistically significant, and overall the matching process improved the homogeneity of the study population.

The difference in the mean change in serum potassium level between the control and treatment groups was $0.17 \mathrm{mmol} / \mathrm{L}$ in the unmatched paired $t$ test analysis $(-0.41 \pm 0.50$ versus $-0.58 \pm 0.39 \mathrm{mmol} / \mathrm{L} ; p=0.039)$ and $0.14 \mathrm{mmol} / \mathrm{L}$ in the propensity score-matched paired $t$ test analysis $(-0.44 \pm 0.29$ 
Table 1. Patient Characteristics

Group; Mean \pm SD or No. (\%) of Patients

Characteristic Control $(n=72[52 \%])$ Treatment $(n=66[48 \%])$

\begin{tabular}{|c|c|c|c|c|}
\hline$\overline{\text { Age (years) }}$ & \multicolumn{2}{|c|}{$69 \pm 17$} & \multicolumn{2}{|c|}{$69 \pm 16$} \\
\hline Sex, female & & (33) & & (39) \\
\hline Index $\mathrm{K}^{+}$level (mmol/L) & \multicolumn{2}{|c|}{$5.1 \pm 0.2$} & \multicolumn{2}{|c|}{$5.3 \pm 0.2$} \\
\hline$\overline{\mathrm{eGFR}(\mathrm{mL} / \mathrm{min})}$ & \multicolumn{2}{|c|}{$59 \pm 27$} & \multicolumn{2}{|c|}{$56 \pm 32$} \\
\hline Urea (mmol/L) & \multicolumn{2}{|c|}{$11 \pm 7$} & \multicolumn{2}{|c|}{$13 \pm 9$} \\
\hline \multicolumn{5}{|l|}{ Concurrent disease } \\
\hline Heart failure & & $(15)$ & 12 & (18) \\
\hline Liver dysfunction* & 8 & $(11)$ & 12 & (18) \\
\hline Diabetes mellitus & 22 & (31) & 19 & (29) \\
\hline \multicolumn{5}{|l|}{ Diet type } \\
\hline Regular & 10 & (14) & 10 & $(15)$ \\
\hline Low K+ & 1 & (1) & 1 & (2) \\
\hline Othert & 61 & $(85)$ & 55 & $(83)$ \\
\hline \multicolumn{5}{|l|}{$\begin{array}{l}\text { Concurrent medications } \\
\text { Increase serum } K^{+}\end{array}$} \\
\hline Dalteparin & 29 & $(40)$ & 25 & (38) \\
\hline ACE inhibitor or ARB & 14 & (19) & 18 & $(27)$ \\
\hline $\begin{array}{l}\text { Aldosterone antagonist or } \\
\mathrm{K}^{+} \text {-sparing diuretic }\end{array}$ & 8 & (11) & 6 & (9) \\
\hline TMP-SMX & 3 & (4) & 5 & (8) \\
\hline High-dose heparin & 3 & (4) & 4 & (6) \\
\hline Nonselective $\beta$-blocker & 2 & (3) & 1 & (2) \\
\hline Other‡ & 2 & (3) & 2 & (3) \\
\hline Calcineurin inhibitor & 0 & (0) & 1 & (2) \\
\hline \multicolumn{5}{|l|}{ Decrease serum $K^{+}$} \\
\hline Basal insulin or sliding-scale insulin & 17 & $(24)$ & 15 & $(23)$ \\
\hline Thiazide or loop diuretic & 16 & $(22)$ & 15 & (23) \\
\hline Salbutamol & 10 & $(14)$ & 13 & $(20)$ \\
\hline Lithium & 1 & (1) & 1 & $(2)$ \\
\hline
\end{tabular}

$\overline{\mathrm{ACE}}=$ angiotensin-converting enzyme, $\mathrm{ARB}=$ angiotensin II receptor blocker, eGFR = estimated glomerular filtration rate, $S D=$ standard deviation, TMP-SMX = trimethoprim-sulfamethoxazole.

*Documented liver function test elevated to 3 times the upper limit of normal upon admission or about the time of index potassium level; documented cirrhosis; documented hepatitis $A, B$, or $C$.

tDiet not specified or diabetic diet.

\#Regular $\mathrm{K}^{+}$supplementation (oral or IV).

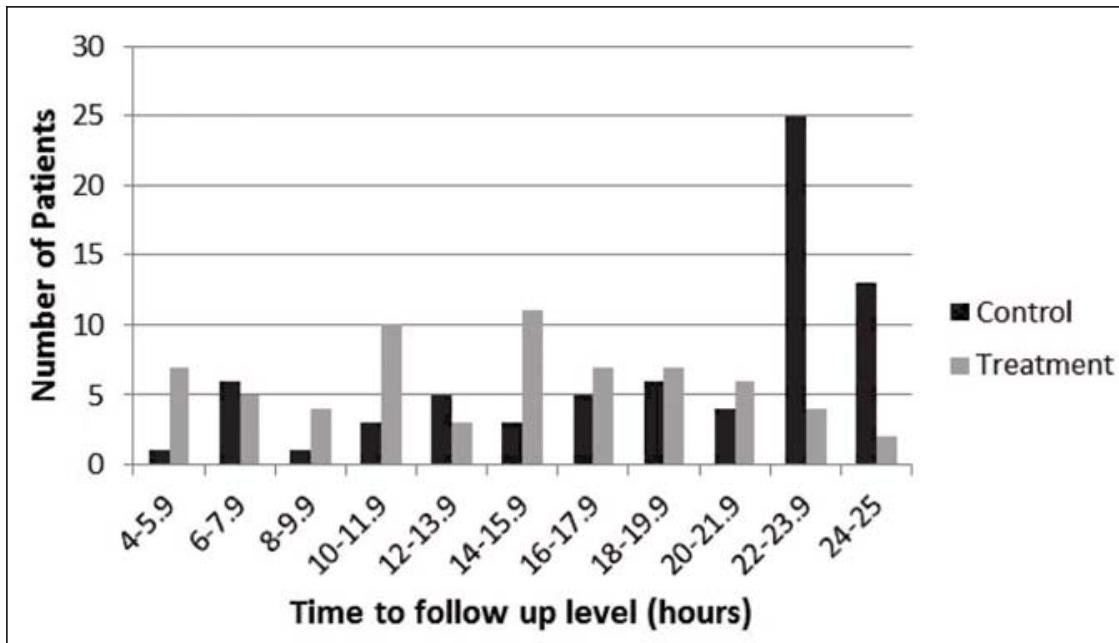

Figure 1. Time to sampling for follow-up serum potassium level. 


\section{Table 2. Results for Propensity Score Matching}

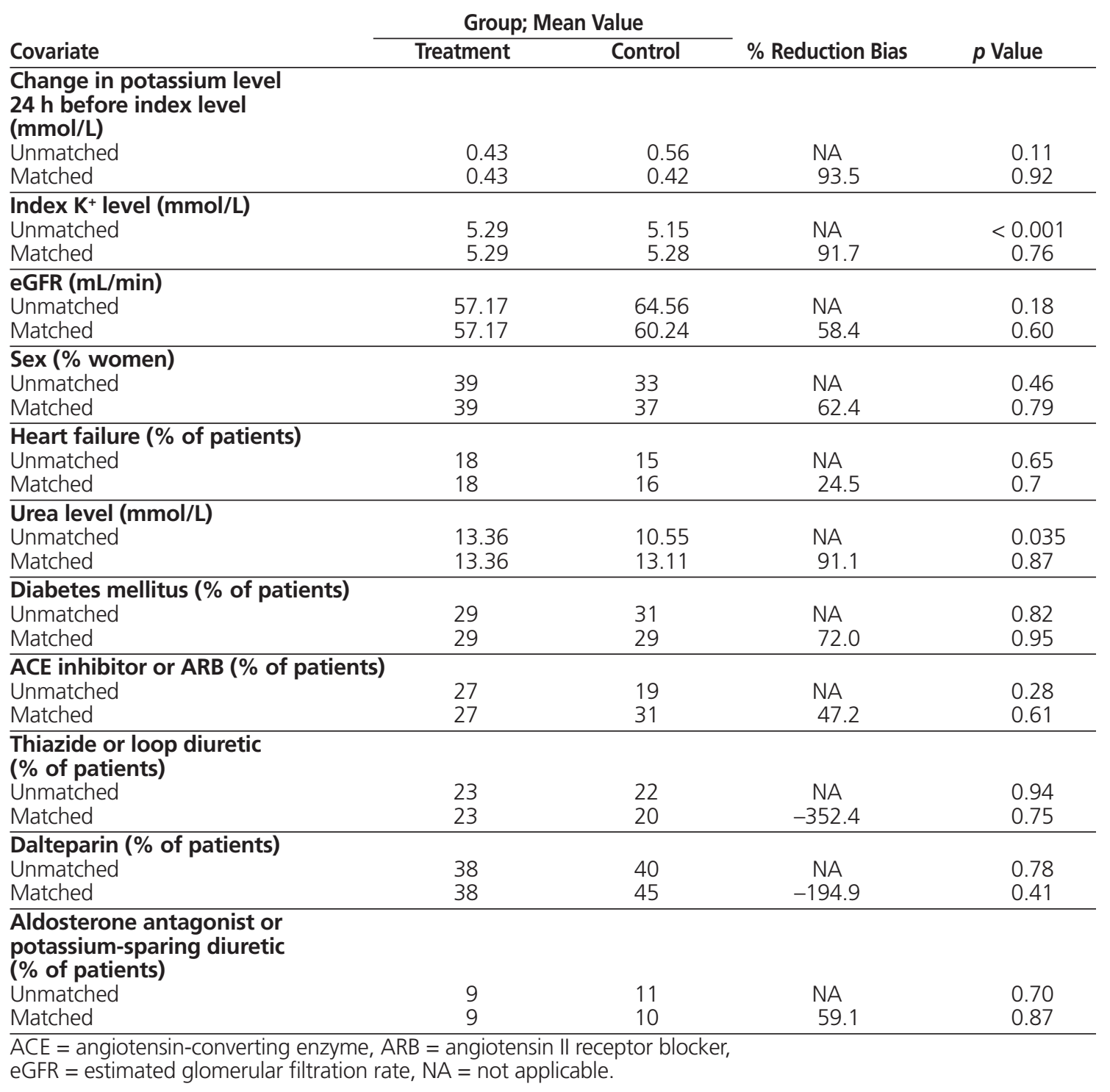

versus $-0.58 \pm 0.39 \mathrm{mmol} / \mathrm{L} ; p=0.026)$. Both results were statistically significant (Figure 2).

There was no significant difference in the mean change in serum potassium level between the groups that received SDS $15 \mathrm{~g}$ and $30 \mathrm{~g}(-0.51 \pm 0.38$ versus $-0.66 \pm 0.40 \mathrm{mmol} / \mathrm{L} ; p=0.13)$ (Figure 3).

Patients' records were screened for documentation of gastrointestinal adverse events such as intestinal necrosis, obstruction, ulceration, perforation, and ischemic colitis. Only one patient (in the treatment group) had a documented nonfatal obstruction, which was likely unrelated to SPS. The patient was seen by a gastroenterologist, who diagnosed pseudo-obstruction secondary to Clostridium difficile enterocolitis.

\section{DISCUSSION}

This study showed a decrease in serum potassium of $0.14 \mathrm{mmol} / \mathrm{L}$ with SPS relative to control. This small effect, below the predetermined minimal clinically important difference of $0.2 \mathrm{mmol} / \mathrm{L}$, is consistent with the results of previous randomized controlled studies but differs from those of uncontrolled studies. The current study used strong methodological techniques, specifically exclusion of patients with strong confounding interventions and matching of patients by means of propensity scores. ${ }^{19}$ Use of these techniques allowed an unbiased estimate of treatment effect more closely mimicking the results of a randomized trial. The $0.58 \mathrm{mmol} / \mathrm{L}$ decrease in 


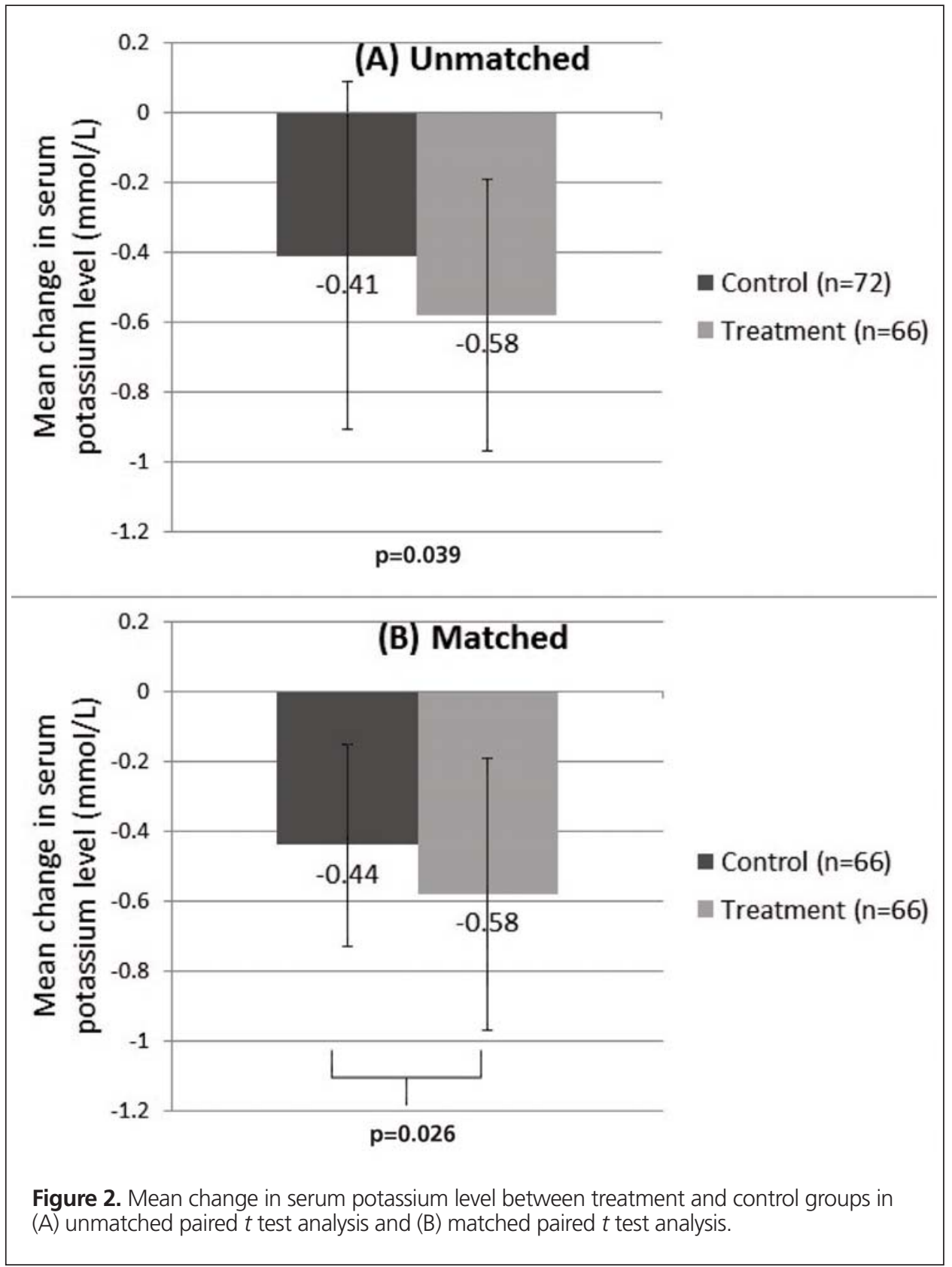

serum potassium seen in the treatment group was numerically smaller than the approximately $1 \mathrm{mmol} / \mathrm{L}$ decrease reported in previous uncontrolled studies. ${ }^{11,12}$ However, those previous studies included patients who received concomitant confounding interventions with SPS, whereas this study excluded all patients with confounding interventions. The concomitant interventions may have biased the results of the earlier studies, making SPS appear more efficacious.

In the current study, propensity score matching was used to minimize heterogeneity of baseline characteristics and to reduce confounding due to nonrandomization. ${ }^{20}$ With this method, a propensity score is generated for each patient on the basis of variables that might influence the clinician's decision to treat with the intervention of interest. ${ }^{20}$ Treated and untreated patients are then matched to maximize the nearness of propensity scores between matched patients. ${ }^{20}$ Many methods are available for matching based on propensity scores, but no single method has been heralded as universally superior. Selection is generally based on the circumstances of the study. ${ }^{21}$ For the current study, the Kernel matching method was used, which allowed data from all 72 control patients to be incorporated. The matched controls are derived from the weighted average of all the control patients, and the weights are inversely related to the nearness in propensity scores between the treatment and control groups. ${ }^{20,22}$ 


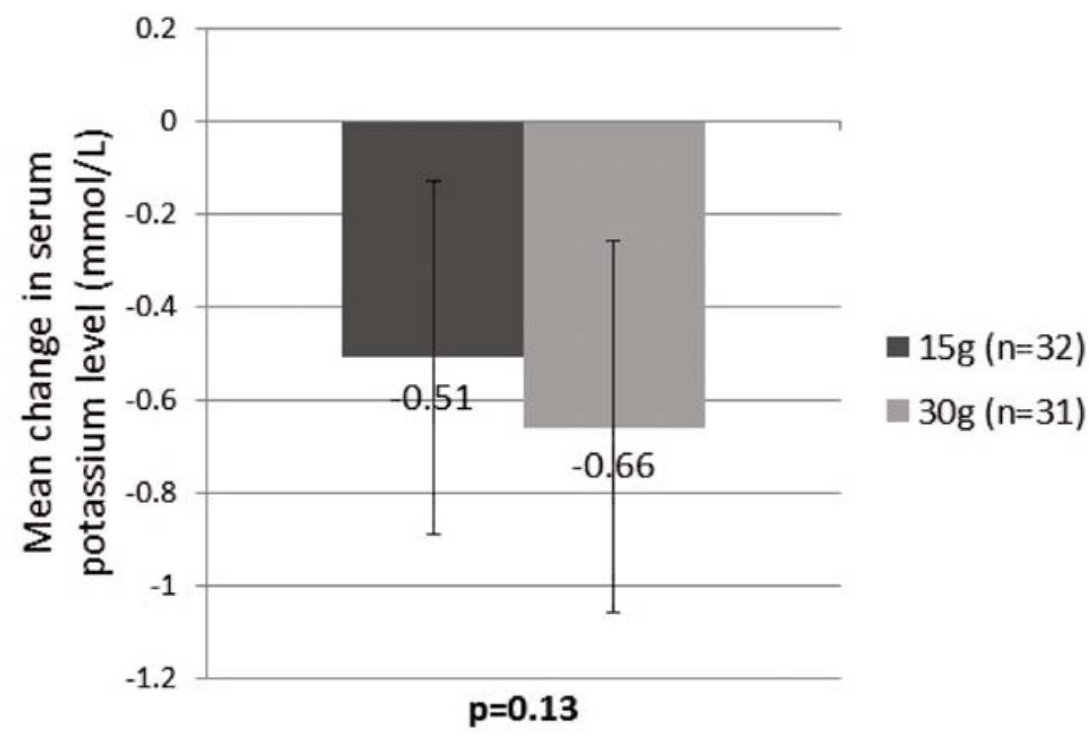

Figure 3. Mean change in serum potassium level between 15-g and 30-g dose of sodium polystyrene sulfonate.

As with all retrospective studies, this study had risks of both bias and confounding. Bias by indication may have occurred if patients at higher risk of worsening hyperkalemia were more likely to be treated with SPS. These higher-risk patients might benefit from SPS, but that benefit would be obscured after comparison with the lower-risk control patients. An attempt was made to avoid this potential bias by including only patients with mild hyperkalemia, who were at low risk of the complications of hyperkalemia and for whom the decision to treat with SPS is often driven by prescriber preference rather than patient-related factors. The aim was to limit bias through stringent exclusion of confounders, but some confounders could not be excluded, and there may have been unknown confounders beyond the exclusion criteria. Also, it was not possible to dictate the time interval between measurement of the index and follow-up potassium levels; as a result, follow-up levels in the treatment group were evenly distributed between 4 and $24 \mathrm{~h}$, whereas more patients in the control group had follow-up levels measured after $22 \mathrm{~h}$. However, the onset of action of SPS is unpredictable and is estimated to occur between 2 and 24 hours. ${ }^{23,24}$ Therefore, the bias may be in favour of either the treatment or control group, depending on whether the effect of SPS was captured with each follow-up level. Similarly, it was not possible to dictate the SPS dosage given. Oral doses of 15 to $60 \mathrm{~g}$ can be used for this indication, but most doses at the study facility were 15 or $30 \mathrm{~g}$. Although no significant difference was found between 15 -g and 30 -g dosing, the existence of a dose-response relationship with higher doses, such as $45 \mathrm{~g}$ or $60 \mathrm{~g}$, could not be ruled out. The effectiveness of repeated doses was not studied.
The small effect of SPS observed in this study suggests that some patients with mild hyperkalemia may be exposed to potentially serious adverse effects with little to no clinically significant benefit. ${ }^{6,8} \mathrm{~A}$ study published in 2009 reported 11 cases of colonic necrosis associated with the use of sorbitol-SPS over the course of 9 years, 4 of which were fatal. ${ }^{25}$ In the same year, the FDA posted warnings about the association between sorbitol-containing SPS and potentially fatal intestinal necrosis (bleeding, ischemic colitis, perforation). ${ }^{26}$ However, in many hospitals, the premixed sorbitol-SPS preparation is the only SPS product available. ${ }^{7}$ With an estimated 5 million SPS doses given annually in the United States (based on an unpublished single-hospital survey result), there is a need for re-evaluation of its effectiveness and safety. ${ }^{7}$

\section{CONCLUSIONS}

In patients with mild hyperkalemia, single-dose oral SPS therapy reduced serum potassium by $0.14 \mathrm{mmol} / \mathrm{L}$ more than control. Although this difference was statistically significant, the small treatment effect observed in this study may not be clinically important. The small therapeutic effect observed in this study and the cost and potential adverse effects of treatment suggest that routine use of SPS may be inappropriate for patients with mild hyperkalemia. Prospective randomized controlled trials would be helpful in further evaluating the effectiveness and safety of SPS in the management of hyperkalemia.

\section{References}

1. Acker CG, Johnson JP, Palevsky PM, Greenberg A. Hyperkalemia in hospitalized patients: causes, adequacy of treatment, and results of an attempt to improve physician compliance with published therapy guidelines. Arch Intern Med. 1998;158(8):917-24. 
2. Moore ML, Bailey RR. Hyperkalaemia in patients in hospital. $N Z$ Med J. 1989;102(878):557-8

3. Shapiro S, Slone D, Lewis GP, Jick H. Fatal drug reactions among medical inpatients. JAMA. 1971;216(3):467-72.

4. Paice B, Gray JM, McBride D, Donnelly T, Lawson DH. Hyperkalaemia in patients in hospital. Br Med J (Clin Res Ed). 1983;286(6372):1189-92.

5. Mahoney BA, Smith WA, Lo DS, Tsoi K, Tonelli M, Clase CM. Emergency interventions for hyperkalaemia. Cochrane Database Syst Rev. 2005;(2): CD003235.

6. Evans KJ, Greenberg A. Hyperkalemia: a review. J Intensive Care Med. 2005;20(5):272-90

7. Sterns RH, Rojas M, Bernstein P, Chennupati S. Ion-exchange resins for the treatment of hyperkalemia: are they safe and effective? J Am Soc Nephrol. 2010;21(5):733-5.

8. Watson M, Abbott KC, Yuan CM. Damned if you do, damned if you don't: potassium binding resins in hyperkalemia. Clin J Am Soc Nephrol. 2010;5(10):1723-6.

9. Drugs@FDA: FDA approved drug products. Silver Spring (MD): Food and Drug Administration (US); [cited 2013 Aug 28]. Available from: www. accessdata.fda.gov/scripts/cder/drugsatfda/index.cfm?fuseaction=Search. Label_ApprovalHistory\#apphist

10. Drug product database online query. Ottawa $(\mathrm{ON})$ : Health Canada; 2012 [cited 2014 Aug 8]. Available from: http://webprod5.hc-sc.gc.ca/dpd-bdpp/. Search term for product name: "Kayexalate".

11. Flinn RB, Merrill JP, Welzant WR. Treatment of the oliguric patient with a new sodium-exchange resin and sorbitol: a preliminary report. $N$ Engl J Med. 1961;264(3):111-5.

12. Scherr L, Ogden DA, Mead AW, Spritz N, Rubin AL. Management of hyperkalemia with a cation-exchange resin. NEngl JMed. 1961;264(3):115-9.

13. Gruy-Kapral C, Emmett M, Santa Ana CA, Porter JL, Fordtran JS, Fine $\mathrm{KD}$. Effect of single dose resin-cathartic therapy on serum potassium concentration in patients with end-stage renal disease. J Am Soc Nephrol. 1998;9(10):1924-30.

14. Emmett M, Hootkins RE, Fine KD, Santa Ana CA, Porter JL, Fordtran JS. Effect of three laxatives and a cation exchange resin on fecal sodium and potassium excretion. Gastroenterology. 1995;108(3):752-60.

15. Kessler C, Ng J, Valdez K, Xie H, Geiger B. The use of sodium polystyrene sulfonate in the inpatient management of hyperkalemia. J Hosp Med. 2011;6(3):136-40.

16. Harel Z, Harel S, Shah PS, Wald R, Perl J, Bell CM. Gastrointestinal adverse events with sodium polystyrene sulfonate (Kayexalate) use: a systematic review. Am J Med. 2013;126(3):264.e9-24.

17. Kidney Disease: Improving Global Outcomes (KDIGO), Acute Kidney Injury Work Group. KDIGO clinical practice guideline for acute kidney injury. Kidney Int Suppl. 2012;2(1):1-138.

18. Kuwabara S, Misawa S, Kanai K, Tamura N, Nakata M, Sawai S, et al. The effects of physiological fluctuation of serum potassium levels on excitability properties in healthy human motor axons. Clin Neurophysiol. 2007;118(2):278-82.

19. Caliendo M, Kopeinig S. Some practical guidance for the implementation of propensity score matching. J Econ Surv. 2008;22(1):31-72.
20. Austin PC. An introduction to propensity score methods for reducing the effects of confounding in observational studies. Multivar Behav Res. 2011 46(3):399-424.

21. Propensity score matching in observational studies. Winnipeg (MB) University of Manitoba, Faculty of Medicine, Manitoba Centre for Health Policy; [cited 2013 Jul 4]. Available from: http://umanitoba.ca/faculties/ medicine/units/community_health_sciences/departmental_units/mchp/ protocol/media/propensity_score_matching.pdf

22. Heckman JJ, Ichimura H, Todd P. Matching as an econometric evaluation estimator. Rev Econ Stud. 1998;65(2):261-94.

23. Kayexalate (sodium polystyrene sulfonate) [package insert]. Laval (QC): Sanofi-Aventis Canada Inc; 2014.

24. Sodium polystyrene sulfonate. In: Lexi-drugs online [database on Internet]. Hudson (OH): Lexicomp, Inc; 2015 [updated 10 Feb 2015; cited 10 Feb 2015]. Available from: http://online.lexi.com. Subscription required to access content.

25. McGowan CE, Saha S, Chu G, Resnick MB, Moss SF. Intestinal necrosis due to sodium polystyrene sulfonate (Kayexalate) in sorbitol. South Med J. 2009; 102(5):493.

26. Safety information: Kayexalate (sodium polystyrene sulfonate) powder. Silver Spring (MD): Food and Drug Administration (US); 2009 Sep [cited 2012 Jul 9]. Available from: www.fda.gov/Safety/MedWatch/Safety Information/ucm186845.htm

Josh Batterink, BSc(Pharm), ACPR, is with the Pharmacy, St Paul's Hospital, Vancouver, British Columbia.

Jane Lin, BSc(Pharm), ACPR, is with the Pharmacy, St Paul's Hospital, Vancouver, British Columbia.

Sarah Hin Mui Au-Yeung, BSc(Pharm), was, at the time this study was conducted, a student in the Bachelor of Pharmacy program, The University of British Columbia, Vancouver, British Columbia. She is now with the Pharmacy, Nanaimo Regional General Hospital (Island Health), Nanaimo, British Columbia

Tara Cessford, BSC(Hon), MD, is with the Department of Internal Medicine, The University of British Columbia, Vancouver, British Columbia.

Competing interests: None declared.

\section{Address correspondence to:}

Josh Batterink

Pharmacy

St Paul's Hospital

1081 Burrard Street

Vancouver BC V6Z 1Y6

e-mail: jbatterink@providencehealth.bc.ca

Funding: None received. 